Wold, J., Lædre, O. and Lohne, J. (2019). "Questionable Practice in the Processing of Building Permits in Norway" In: Proc. 27th Annual Conference of the International. Group for Lean Construction (IGLC), Pasquire C. and Hamzeh F.R. (ed.), Dublin, Ireland, pp. 1151-1162. DOI: https://doi.org/10.24928/2019/0214. Available at: 〈www.iglc.net>.

\title{
QUESTIONABLE PRACTICE IN THE PROCESSING OF BUILDING PERMITS IN NORWAY
}

\author{
Jonas Wold ${ }^{1}$, Ola Lædre ${ }^{2}$ and Jardar Lohne ${ }^{3}$
}

\begin{abstract}
In recent years, several cases of questionable practice in the processing of building permits in Norway have been revealed. Meanwhile, authorities claim the risk of corruption associated with the processing of building permits is more obvious than before.

This study investigates the size of the opportunity space for questionable practice in the processing of building permits. Questionable practice includes both illegal practice in the form of corruption and legal, but unethical practice. Further, this paper examines if the opportunity space is being exploited, before suggesting countermeasures. A greater predictability in the processing could increase the Lean Construction and reduce costs. It has been conducted a literature review and seven interviews with caseworkers and heads of departments in five municipalities in Norway. The study is limited to the examined municipalities.

The results show that the processing of building permits is based on great responsibility delegated to the caseworkers and that there is a certain opportunity space. However, this space is not being exploited in the examined municipalities. Measures, e.g. implementing a new processing system, are anyhow proposed.
\end{abstract}

\section{KEYWORDS}

Sustainability, promise, trust, building permits, questionable practice.

\section{INTRODUCTION}

Unethical and unlawful practice has been reported to have gained significant impact within the Norwegian construction industry over the last years. Based on research analyses (e.g. Lohne et al. 2019), reports from official agencies and others (e.g. Departementene 2019; Riksrevisjonen 2015-16a, 2015-16b) and industry initiated reports (e.g. Slettebøe et al. 2003; Andersen et al. 2014), there appears to be a widespread understanding that presentday efforts towards countering crime are failing to control what is perceived to be an

1 Student M.Sc., Department of Civil and Environmental Engineering, NTNU - Norwegian University of Science and Technology, Trondheim, Norway, +47 41403 086, jonaswold@ hotmail.com

2 Professor, Department of Civil and Environmental Engineering, NTNU - Norwegian University of Science and Technology, Trondheim, Norway, +4791189 938, ola.ladre@ntnu.no

3 Researcher, dr. art., Department of Civil and Environmental Engineering, NTNU - Norwegian University of Science and Technology, Trondheim, Norway, +47 93444 930, jardar.lohne@ @ntnu.no 
escalation of criminal activities within the Norwegian AEC-industry over the last two decades.

In addition, current efforts (Engebø et al. 2016; Kjesbu et al. 2017a, 2017b; Richani et al. 2017; Lohne et al. 2015; Skovly et al. 2017) show that important criminal activity is carried out in sectors that are not within the present scope of the Norwegian control authorities. These include supply chain management issues, identity issues, and building process related challenges, such as those occurring during the design and handover phases. Considering the gravity of the challenges, the topic of felonious activity in the AECindustry seems, however, severely under-researched within the research literature. As Walker (2014) comments, "[t]here is a dearth of papers" on unethical activity within the industry. Of particular interest to the analysis reported on in this paper, very little seems to have been done concerning corruption challenges within this context so far.

In January 2019, Transparency International (2019) published their corruption perceptions index for 2018, and with a seventh place, Norway yet again confirms its position as one of the world's least corrupt countries. Meanwhile, there are regularly investigations of public employees suspected for questionable work. One field with such disclosures over the last years is the processing of building permits. The "Drammen-case" is the latest example, where two caseworkers in the municipality of Drammen were sentenced to 3,5 and 6 years of prison for aggravated corruption. In addition, Norwegian authorities maintain that the risk of corruption in the processing of building permits has increased (Økokrim 2018).

Questionable practice includes both legal but unethical practice, and illegal practice in the form of corruption. Although there is a great deal of international research on the subject of questionable practice, especially on the occurrence of corruption, the conditions in developing countries have been given the most attention. The amount of research on questionable practice in developed countries has proven more scarce. With regards to processing of building permits in developed countries, the amount of research seems surprisingly limited when considering the economical values in play.

In the aftermath of the revealed cases characterised by questionable practice in Norway, the standard procedure has been performing an external scrutiny, including a following report. However, these reports have been specific for the involved municipality, with a limited transfer value to other municipalities. This study provides an outline of preventive measures applicable to the majority of municipalities. Side effects include increased predictability in the processing of building permits and reduced costs in the start-up phase. These are both in accordance with the principles foundational to Lean Construction. The study addresses the following research questions:

1) What is the opportunity space for questionable practice in the processing of building permits?

2) Is the opportunity space being exploited?

3) How can one prevent the opportunity space from being exploited?

The study is limited to the processing of the matters regarding the building itself, e.g. height restrictions, footprint etc. The study has been carried out with the perspective of the caseworkers, and examines the six following axes: processing system, workload, control procedures, organizational structure, size of municipality and local interests in the 
municipality. Each axis is stretching between extremes in each area, and the study examines whether a certain placement on the axis has an impact on the opportunity space for questionable practice.

\section{METHODOLOGY}

In the work of this study, it has been conducted a scoping literature review, a document study of relevant scrutiny reports and seven semi-structured interviews.

The literature review followed the prescriptions of Arksey and O'Malley (2005). It began with a systematic literature search. Searches were conducted in the following databases, with both Norwegian and English keywords and phrases: Google Scholar, Oria, Web of Science and Research Gate. In the selection of relevant literature, title, keywords, abstract and conclusion were considered - in the given order. If the literature still were interesting after reading the conclusion, the whole text was read and evaluated based on credibility, objectivity, accuracy and suitability. Approximately 40 articles were studied, concerning both legal, but unethical practice, and corruption.

In the document study, legal cases, scrutiny reports and newspaper articles concerning questionable practice in the processing of building permits were examined. The main documents were the judgement and the scrutiny report from the "Drammen-case", which served as a basis for the interview guide of this study. In addition, documents and surveys regarding questionable practice in the Norwegian working life in general were studied.

The main source of information was seven interviews with municipal caseworkers and heads of department processing building permits on a daily basis. The research was limited to five municipalities in Norway, anonymized and listed in table 1 . The municipalities were chosen from different criteria, as number of citizens, geographic characteristics (e.g. mountain areas vs. shoreline) and availability. As this topic is sensitive, the interviewees and their municipalities have been anonymized and randomized.

Table 1: Overview of municipalities and number of interviewees

\begin{tabular}{ccc}
\hline Municipality & Number of citizens & Number of interviewees \\
\hline A & $1000-5000$ & 1 \\
B & $1000-5000$ & 1 \\
C & $5000-10000$ & 1 \\
D & $15000-20000$ & 3 \\
E & $>25000$ & 1 \\
\hline
\end{tabular}

Five of the selected interviewees were caseworkers, while two were heads of the respective department in their municipality. This approach was to obtain different perspectives on the issue. All the interviews were semi-structured and individual in accordance with the prescriptions of Yin (2003), with an interview guide that was supplemented by spontaneous follow-up questions when applicable. The interviewees were solely asked about the conditions in their own department. Due to the critical positions of the interviewees, they can adjust their explanations to their own interests. However, the general impression is that the interviewees gave unbiased answers. The interviews were recorded and transcribed, and the interviewees have approved the transcriptions of the respective interviews. 


\section{THEORETICAL FRAMEWORK}

\section{QUESTIONABLE PRACTICE}

In this study, questionable practice in the processing of building permits is defined as processing of building permits that are in violation of the law or considered unethical. Illegal processing of building permits is limited to corrupt practice. Furthermore, public officials who process and issue building permits are referred to as caseworkers. Opportunity space refers to questionable practice in the processing of building permits, and is defined as the entire span of opportunities for caseworkers. This includes both legal (but unethical) opportunities given by delegated authorizations and illegal opportunities, as for example issuing permits despite lack of documentation or issuing permits that should not have been issued. Applicants are those who apply for a building permit.

Figure 1 illustrates different types of behaviour. Unethical, but legal behaviour is illustrated with a target. There is a clear distinction between unlawful and lawful behaviour, as this is regulated by the law. However, the distinction between ethical and unethical behaviour is more unclear and complex, illustrated with a zigzag line.

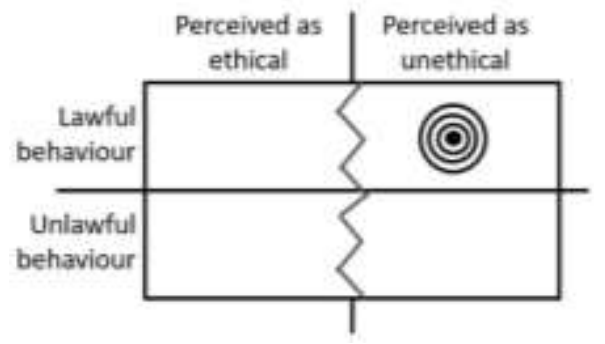

Figure 1: Different types of behaviour (Lohne et al. 2017, figure 1)

Bruce (1994) defines an ethical employee as one who works on the behalf of the public and who prioritizes the benefits of the public and the government, as well as not taking part in illegalities. She states that unethical employees are less productive and that problem behaviour led to costs of over 195 billion USD in 1990, only in the U.S. (Bruce 1994).

The financial consequences of corruption are immense, and IMF (2016) estimated in 2016 that bribery alone amounted for 1,5-2 trillion USD worldwide. Corruption may lead to discrimination and incorrect decisions (Transparency International Norway 2014), and a reduced trust in the public (Sedlenieks 2003; Eriksen 2014; Chiodelli \& Moroni 2015). Transparency International (2011) presented numbers describing the construction industry as the most corrupted one, and earlier on, De Jong et al. (2009) estimated the cost of corruption in the construction industry to be approximately 500 billion USD worldwide. When it comes to issuing of building permits, corruption can result in illegal and hazardous buildings (Dølvik \& Medalen 2017), with loss of lives as a direct consequence.

There is a gray zone of behaviour that renders corruption hard to define. Even though there is an international consensus on what actions are considered corrupt, e.g. bribery, blackmailing, fraud and embezzlement (Locatelli et al. 2017), some authorities refrain from defining the term. This may be a consequence of definitions being too narrow and thus 
leading to many corrupted acts not being pursued (Council of Europe 1999). In this study, the English translation of the Norwegian Penal Code's definition of corruption is used (Lovdata 2015, section 387): A penalty of a fine or imprisonment for a term not exceeding three years shall be applied to any person who a) for himself/herself or others demands, receives or accepts an offer of an improper advantage in connection with the conduct of a position, an office or performance of an assignment, or b) gives or offers any person an improper advantage in connection with the conduct of a position, an office or performance of an assignment. The Penal Code also operates with the term aggravated corruption, with a maximum sentence of ten years. In short terms, this means the corruption is of a more severe degree.

\section{QUESTIONABLE PRACTICE IN NORWAY}

Limited research of the prevalence of unethical but legal behaviour in Norway has been identified in this study. Surveys tell, however, that public officials are aware that unethical behaviour is occurring in the municipalities (Kantar TNS \& Søreide 2018). These prove problematic, though, since they include both illegal and legal behaviour in the concept of unethical behaviour. In Norway, corruption is punished harder than other forms of economic crime (Ministry of Justice and Public Security 2009). Despite the deterrent effect this should have, 51 cases of corruption were revealed in Norway in the period 2006-2018 (Transparency International 2018). Meanwhile, there are surveys telling that one to four out of ten heads of departments in Norwegian municipalities have knowledge of situations involving improper advantage (Kantar TNS \& Søreide 2018).

\section{THE DRAMMEN-CASE}

The most severe and comprehensive case of questionable issuing of building permits was the Drammen-case. Two caseworkers in the municipality of Drammen were sentenced to prison for 16 cases of aggravated corruption (Lovdata 2018). Caseworker 1 was sentenced for further cases of aggravated corruption and forgery, and for receiving approximately 130000 USD in bribes. She got sentenced with six years of prison and confiscation of the money. Caseworker 2 got three years and six months of prison for conveying cases to caseworker 1 while knowing of this corruption, and a confiscation of the 13000 USD he got for doing so. Caseworker 1 had a second job as a private architect, drawing applications on the behalf of applicants. In her job as a caseworker, she approved applications with her own drawings, and counterfeited the signature of the head of her department in the building permits. In the Drammen-case, the convicts behaved both unethical and unlawful.

\section{THE SIX AXES}

Deloitte (2018) presented a scrutiny report from the Drammen-case. Based on this report, the six axes illustrated in figure 2 were established for this study. The axes emerged as they were used to explain the opportunity space for questionable practice. This study examines whether a particular placement on the axis leads to a possible opportunity space. 


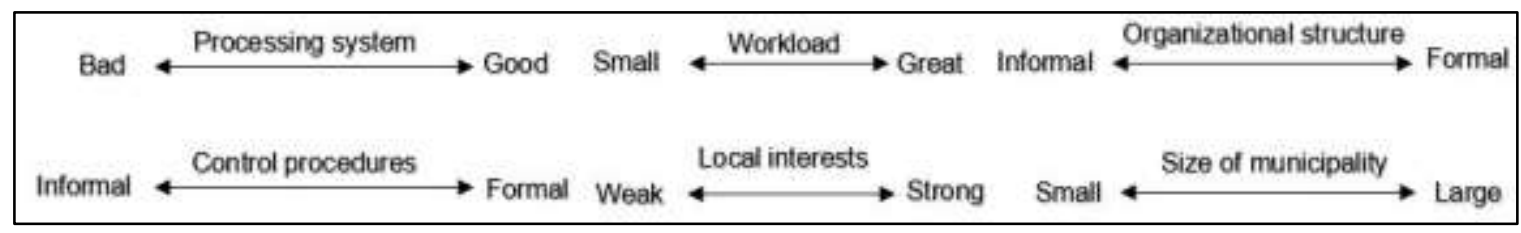

Figure 2: The six axes studied.

\section{Description of the six axes}

- Processing system: Different municipalities operate with different processing systems, and it is examined if these systems offer space for questionable procedural work.

- Workload: The study examines if heavy workload makes it easier to downgrade the control procedures and how this might affect the opportunity space.

- Organizational structure: The organizational structure in the different municipalities have been studied to see whether different structures create or limit the opportunity space.

- Control procedures: It is examined if the control procedures are more informal and verbally incorporated, or formal and embedded in governing documents, and whether this impact the opportunity space.

- Local interests: It is assumed that actors who are important for the municipality as for example entrepreneurs or housing developers - try to take advantage of this when applying for building permits. The study examines if such actors exist and whether they try to influence the process.

- Size of the municipality: In small municipalities, the caseworkers may know the applicants on a personal level to a greater extent than in a larger municipality, and one can assume that this may create challenging situations in the procedural work.

\section{RESULTS AND DISCUSSION}

In this chapter, results and discussions from each of the above described six axes are presented in consecutive paragraphs and in relation to the three research questions formulated in the introduction.

\section{Processing System}

The systems used in the examined municipalities were either ePhorte, ESA or the recently developed eByggesak. In ePhorte and ESA, the caseworkers can process a building application without any external approval. However, both systems generate a list with processed building permits. This list is given to the head of the department, who uses it in meetings with the politicians, e.g. an executive council. This works as a control of irregularities. Municipality $\mathrm{E}$ is the only one using the new system eByggesak - under testing for two years - and here, caseworkers cannot process a building permit without external control. None of the interviewees have experienced any exploitation of their processing system in terms of questionable practice. Regarding countering measures, several of the interviewees said that even though they have not tried eByggesak, they have 
heard it is more customized to their work, as well as being less exposed to questionable practice. This is confirmed by the interviewee from municipality E, which earlier used ESA. Even though the high level of traceability in the processing systems does not reduce the opportunity space itself, it makes it more difficult to get away with questionable practice.

ePhorte and ESA are based on a certain degree of responsibility delegated to the caseworkers. The systems appear to have limited transparency, so without any further implemented control or quality assurance system it is hard to ensure that procedures are followed in accordance with the regulations. ESA was the processing system in the Drammen-case, but the scrutiny report does not say anything about any produced agenda of processed building permits. Almost none of the interviewees had reflected on the possibilities of exploiting the processing system for questionable practice, so there is some uncertainty regarding this matter. However, it seems that eByggesak, which reduces the opportunity space, will be commercially available for all municipalities during spring 2019.

\section{WORKLOAD}

Almost without exception, the interviewees said they have a heavy workload and that their resources do not conform with their tasks. The interviewee in municipality $\mathrm{C}$ says short deadlines lead to a reduced internal control, creating situations where "things can slip". In municipality B, the head of department routinely controls and approves every approval or refusal of the application, and the interviewee says a possible consequence of the great workload is reduced quality of this control. None of the interviewees say they know about the high workload being exploited to conduct questionable practice. The interviewees in municipality D say implementation of eByggesak would free resources that could be used on supervision of built buildings - which would reduce the possibility for getting away with building something else than permitted.

It seems that no matter the size of the municipality, the workload is high, and this potentially lead to an opportunity space, for example when it comes to control of built buildings. Whether this opportunity space is exploited depends on the remaining internal control. The caseworkers seem to be more worried about that high workload could, unconsciously, lead to wrong decisions rather than questionable ones. A consequence of this could be complaints from the applicants or neighbours - resulting in an even greater workload for the caseworkers - thus creating a vicious circle.

\section{ORGANIZATIONAL STRUCTURE}

Naturally, the organizational structure in the small municipalities A, B and C is small, with a short vertical distance from bottom to top. These caseworkers cooperate with other disciplines, e.g. zoning. With few caseworkers in the municipalities, the transparency makes it difficult to hide questionable practice. The larger municipalities D and E are organized without the same interdisciplinary cooperation. An important role in the structure are politicians, that can overrule building permits partly given on administrative discretion. In municipality $\mathrm{C}$, the interviewee says politicians sometimes contact caseworkers directly, demanding specific applications to be treated politically. This is more difficult in municipality $\mathrm{E}$, as regulations require that politicians go through several persons 
with such requests. Even though none of the interviewees have experienced this as a great problem, an interviewee in municipality D says:

"That discretion, where no one can accuse (politicians) for doing something illegal, even though it's not ethically correct... that's maybe where the greatest opportunity space lies".

It seems that the informal structure in small municipalities makes it hard to hide questionable practice, as transparency seems to reduce the opportunity space. On the other hand, in large organizations, the separation of disciplines reduces the opportunity space. Whether political decisions can be tainted by personal agendas is a particularly interesting issue regarding unethical, but legal behavior. This topic is complex, and actors with unethical behaviour can hide behind the law. As this is a local democracy issue, every municipality will experience such challenges.

\section{CONTROL PROCEDURES}

Mostly, the interviewees maintain that there is no enshrined framework for control procedures for processing building permits. Instead, the quality assurance and internal control systems are based on incorporated routines, with a lot of responsibility delegated to the caseworkers. For instance, in municipality A, B and C, the caseworkers have the right to sign a building permit themselves, but there is a routine of forwarding processed applications to the head of department for control, no matter how uncontroversial the building permit is. In municipality $\mathrm{D}$, the caseworkers only did this if they wanted a quality check. The exception is municipality E, where the processing system eByggesak is designed in such a way that the caseworkers are deprived the right to sign, and the building permits have to be approved at several organizational levels.

The interviewee in municipality B considers the greatest opportunity space comes with the possibility of hastening applications through the system. This saves waiting time for the applicant, and the interviewee believed this would not be detected. In municipality D, the caseworkers also have this opportunity. This is by intention, as they earlier had a queue system where they had to process the oldest case. It caused time overruns and accumulation of cases, as many applications missed documents necessary for processing.

There are municipal differences regarding secondary jobs. In municipality $\mathrm{C}$, the caseworkers are not allowed to have a second job that may conflict with their work. In municipality B there are no routines concerning this. The interviewee in municipality B formerly worked with building permits for a local contractor. When she started working for municipality office, no rules prevented her from processing applications from her former employer. However, on her own initiative, she refrained from processing their applications for over one and a half year, as she felt it would be "too close".

The legitimacy in the procedural work is based on delegated responsibility to the caseworkers. The interviewees maintain that this reduces bureaucracy and shortens processing time. However, responsibility may be subject to abuse. A key precondition in the Drammen-case was the main convict's second job as an architect, and it is worryingly that most of the studied municipalities have no clear guidelines for such second jobs. Another transferable issue from the Drammen-case is the hastening of building permits. The main convict often finished applications the same day they got registered, sometimes 
even in just a few minutes. At the same time, it seems too rigid to impose the caseworkers to process building permits in their inbounding order, as this create delays. A system detecting suspiciously fast building permit processing is a possible solution of this issue.

\section{LOCAL INTERESTS}

The interviewee in municipality $\mathrm{C}$ has felt the pressure of making "easy choices" to stop nagging from applicants. The interviewee in municipality B shares these experiences, as she has felt the pressure from applicants to practice questionable casework without being offered any personal gains. She says:

"They think it's easier for them to get an application approved, than for others".

Two of the interviewees in municipality D say they have felt such pressure several times, and that they have felt a certain discomfort after they have been invited to coffee or been given wine or flowers. One of the interviewees was once given a bag of pastry during a meeting with an applicant, which she refused to accept. She says:

"I'm very glad I refused to accept it, because later on, his application was rejected. But he built nevertheless, which was detected, and it became a terrible case".

In municipality $\mathrm{D}$, the caseworkers' department receives an anonymous cake each Christmas. However, they think this is just an unknown applicant wanting to express a general gratitude. The interviewees tell such episodes were much more common 15-20 years ago, and that the frequency of such gifts has been significantly reduced the later years, in line with an increased attention on questionable behaviour in the society as a whole.

In several of the studied municipalities, there are strong local interests, but such pressure does not create an opportunity space itself. However, it can make caseworkers more prone to exploit the already existing opportunity space, mainly by hastening cases through the system. In most of the studied municipalities, there are no guidelines of how to deal with such pressure. It is up to the caseworkers to not make promises, show selfdiscipline and make correct judgements of right and wrong. One method to relieve the pressure in such situations could be to forward these applications to political treatment.

\section{SIZE OF MUNICIPALITY}

It seems from the interviews that living and working in a small municipality, where "everyone knows everyone", can be challenging. The interviewee in municipality C says:

"I know about people quitting as caseworkers, as certain cases have given them too much of a burden".

The caseworkers living in the same municipality as they work experience a greater pressure from acquaintances to conduct questionable practice compared to those living in another municipality. It should be noted that this type of pressure has been of a non-profitable character for the caseworkers. The interviewees living and working in the bigger municipalities have not felt the same kind of pressure. All are very aware of this issue and refrain from processing applications where they know the applicant too well, and the interviewees have never succumbed to the pressure of conducting questionable practice. 
The issue of the size of the municipality can be hard to handle, as one cannot deprive caseworkers the opportunity to live where they want. One can not monitor which friends they have, neither. A solution may be an increased attention on delegating such cases to others, and to inform of what problems that may arise from not doing so. The latter may explain why the interviewee in municipality $\mathrm{C}$ is quick to renounce such applications.

\section{CONCLUSION}

This study has outlined measures against questionable practice in the processing of building permits. It has unveiled a certain opportunity space for questionable practice in the processing of building permits, and that whether caseworkers exploit this space or not may depend on their ethos, understood as their personal moral stance. This space is illustrated as unethical, but lawful behavior in figure 1. Unethical, but lawful behavior is possible, and municipalities have few possible sanctions against caseworkers that operate here. Unlawful behavior is possible, but will be punished according to the penal code. This opportunity space exists because the caseworkers are delegated great responsibility. In most of the examined municipalities, prominent opportunities are for example signing building permits without a required external control or forwarding applications in the application queue.

Interviewees tell that the opportunity space is not exploited in the examined municipalities, due to the self-discipline of the caseworkers and the incorporated routines in the municipalities' internal quality assurance systems. This said, caseworkers that want to, can exploit the space for questionable practice. Caseworkers are regularly pressured to conduct questionable practice. Even though it seems challenging to outdo the opportunity space, examples of preventive measures that reduce this space are listed in table 2 . It should be pointed out that all measures are not relevant for all municipalities, as they are organized somewhat different.

Table 2: Preventive measures that reduce opportunity space

\begin{tabular}{|c|c|c|}
\hline Number & Measure & Reason \\
\hline 1. & $\begin{array}{c}\text { Implementing a more customized } \\
\text { processing system, e.g. } \\
\text { eByggesak. }\end{array}$ & $\begin{array}{c}\text { Will structure the casework, and thereby reduce } \\
\text { the opportunity space, as well as freeing up } \\
\text { resources. }\end{array}$ \\
\hline 2. & $\begin{array}{l}\text { Detection system at suspiciously } \\
\text { short processing times. }\end{array}$ & $\begin{array}{c}\text { A very short processing time may indicate } \\
\text { questionable procedural work. }\end{array}$ \\
\hline 3. & $\begin{array}{l}\text { More formalized routines and } \\
\text { regulations regarding secondary } \\
\text { jobs and duties outside work. }\end{array}$ & $\begin{array}{l}\text { Reducing the risk of conflict of interest, while } \\
\text { increasing the caseworker's understanding of } \\
\text { when they are disqualified. }\end{array}$ \\
\hline 4. & More caseworker resources. & $\begin{array}{l}\text { Increases endurance against pressure to } \\
\text { conduct questionable practice. }\end{array}$ \\
\hline
\end{tabular}

This has been a study of a relatively unexplored topic. The topic should be studied from other perspectives, for example the perspectives of applicants and politicians. It is also suggested to conduct a second study of this very issue when more municipalities have implemented and used the new system eByggesak, to see the effect of this measure. 


\section{REFERENCES}

Andersen, R.K., Eldring, L., and Roed Steen, J. (2014) "Privatmarkedet i byggenæringen - Usynlig arbeidsmarked i de tusen hjem", FAFO, Oslo.

Arksey, H., and O'Malley, L. (2005). "Scoping studies: towards a methodological framework." International Journal of Social Research Methodology, 8(1), 19-32.

Bruce, W. (1994). "Ethical People Are Productive People." Public Productivity \& Management Review, 17(3), 241.

Chiodelli, F., and Moroni, S. (2015). "Corruption in land-use issues: a crucial challenge for planning theory and practice." Town Planning Review, 86(4), 437-455.

Council of Europe. (1999). Explanatory Report to the Criminal Law Convention on Corruption. European Treaty Series, Council of Europe.

de Jong, M., Henry, W. P., and Stansbury, N. (2009). "Eliminating Corruption in Our Engineering/Construction Industry." Leadership and Management in Engineering, 9(3), 105-111.

Departmentene (2019) "Strategi mot arbeidslivskriminalitet [Strategy against work related crime]", Norwegian Government, Oslo, Norway.

Deloitte. (2017). Granskning, Byggesaksavdelingen - Drammen kommune.

Dølvik, T., and Medalen, T. (2017). "Korrupsjonsfaren i plan- og byggesaker må tas mer alvorlig." $<$ https://www.dt.no/meninger/korrupsjonssaken/drammen/korrupsjonsfareni-plan-og-byggesaker-ma-tas-mer-alvorlig/o/5-57-631230 > (Nov 12, 2018)

Engebø, A., Lohne, J., Rønn, P.-E., and Lædre, O. (2016) "Counterfeit Materials in the Norwegian AEC-Industry". Proceedings of the 24th Annual Conference of the International Group for Lean Construction.. Boston: International Group for Lean Construction 2016 ISBN 978-0-9977376-2-2. pp 13-22

Eriksen, B. (2014). A bekjempe et samfunnsonde. Gyldendal Norsk Forlag, Oslo.

IMF. (2016). Corruption: Costs and Mitigating Strategies. Staff Discussion Note.

Kantar TNS, and Søreide, T. (2017). Status og råd for etikkarbeid i kommunesektoren. OE, Oslo Economics.

Kjesbu, N. E., Engebø, A., Lædre, O., and Lohne, J. (2017a), Counterfeit, Fraudulent and Sub-Standard Materials: The Case of Steel in Norway. I: 2017 Lean and Computing in Construction Congress (LC3) - Proceedings of the Joint Conference on Computing in Construction (JC3). Heraklion, Crete, Greece: International Group for Lean Construction 2017 ISBN 978-0-9565951-8-8. s. 805-812

Kjesbu, N. E., Engebø, A., Lædre, O., and Lohne, J. (2017b), Countering counterfeit, fraudulent and sub-standard materials in construction. Countermeasures to avoid the use of counterfeit, fraudulent and sub-standard steel materials in the Norwegian construction industry. In Proceedings 2017 12th International Scientific and Technical Conference on Computer Sciences and Information Technologies (CSIT)

Locatelli, G., Mariani, G., Sainati, T., and Greco, M. (2017). "Corruption in public projects and megaprojects: There is an elephant in the room!" International Journal of Project Management, 35(3), 252-268. 
Lohne, J., Svalestuen, F., Knotten, V., Drevland, F. O., and Lædre, O. (2017). "Ethical behaviour in the design phase of AEC projects." International Journal of Managing Projects in Business, 10(2), 330-345.

Lohne, J., Kjesbu, N. E., Engebø, A., Young, B., and Lædre, O. (2019), Scoping literature review of crime in the construction industry, Journal of Construction and Engineering Management

Lovdata. (2015). The Penal Code.

Lovdata. (2018). TDRAM-2017-169290.

Ministry of Justice and Public Security. (2009). Om lov om endringer i straffeloven 20. mai $2005 n r .28$.

Richani, Y. L., Klakegg, O. J., and Lohne, J. (2017) "Drivers and consequences of identity abuse in the AEC-industry". Procedia Computer Science 2017 ;Volum 121. s. 337-344

Riksrevisjonen (2015-16a) "Riksrevisjonens undersøkelse av myndighetenes arbeid mot sosial dumping ved offentlige anskaffelser", Dokument 3:14 (2015-2016), https://www.prosjektnorge.no/wp-content/uploads/2017/11/sosialdumping-krim-

BAE.pdf, consulted 240718

Riksrevisjonen (2015-16b), "Riksrevisjonens undersøkelse av myndighetenes innsats mot arbeidsmiljøkriminalitet”, $\quad$ Dokument 3:15 (2015-2016), https://www.prosjektnorge.no/wp-content/uploads/2017/11/arbeidsmiljokriminalitetkrim-BAE.pdf, consulted 240718

Sedlenieks, K. (2003). Corruption in the process of issuing building permits.

Slettebøe, A., Buseth, H., Gangås, B., Wold, E., Mo, N., Melleby, S. and Anskau, E. (2003) "Seriøsitet i byggenæringen", FAFO, Oslo.

Skovly, M., Mørenskog, A. R., Engebø, A., Lædre, O., and Lohne, J. (2017) "Measures to counteract work-related crime - airport developments in Norway". Procedia Computer Science 2017 ;Volum 121. s. 664-671

Transparency International. (2011). Bribe Payers Index.

Transparency International Norway. (2014). Beskytt kommunen! Håndbok $i$ korrupsjon.

Transparency International Norway. (2018). Korrupsjonsdommer i Norge 2003-2017.

Transparency International. (2019). Corruption Perceptions Index 2018.

Yin, R. K. (2003). Case study research: design and methods. Applied social research methods series, Sage Publications, Thousand Oaks, California.

Walker, D. (2014), "Editorial", International Journal of Managing Projects in Business, Vol. 7 No. 4, p. 768.

Økokrim. (2018). Trusselvurdering 2018. Oslo. 